\title{
歯科に関連ある気道食道の異物
}

\section{小野 譲・斎藤誠次・野本種邦}

\section{Foreign Bodies of Dental Origin in Air and Food Passages}

Jo Ono, M.D., Seiji Saito, M.D. and Tanekuni Nemoto, M.D.

Dept. of Otolaryngology and Broncho-esophagology Keio University School of Medicine, Tokyo

Accidents of foreign bodies of dental origin constitute not an uncommon occurrence. Our statistics show that out of a total number of 7,536 foreign bodies, dental objects numbered 315 or 4 percent of the total.

During 11 years ending December, 1972, there were 1,593 patients treated at Keio University Hospital with diagnosis of foreign bodies in the air and food passages. Of this number 162 patients were admitted to the hospital with diagnosis of foreign bodies in the tracheobronchial tree and 116 of the esophagus. In this series 64 or 23 per cent were of dental origin.

An analysis of endoscopically removed dentures reveals the following: Of 61 partial dentures 45 were of the upper and 16 of the lower dentures. Less than 4 teeth were attached to each of 46 dentures but in one denture 14 teeth were attached. Thirty of fifty per cent of denture plates were found to be defective or partly broken. In 40 of 51 clasps, 80 per cent, were found broken, abonomally bent, or loosely attached to the plate.

Interesting clinical features and pitfalls in diagnosis and treatment have been described.

\section{Iはじめに}

気道及び食道の異物事故は，いつでも，どこ でも，誰にでも起り得る不虑の出来事である。 そのなかで特殊な位置を占めているのが歯科関 倸異物であろう。

このことは(1)歯科に関連ある異物事故が比較 的多い，(2)この事故は人命を弯やかす危険性が ある，(3)義歯異物の摘出には独自の創意と工夫 が要求される，(4)医療紛争のきつかけとなる等 による。

われわれは義歯異物を中心として臨床上の特 徵, 摘出義歯の実態, 事故防止の対策等につい て考察の一端を述べてみたいと思う。

\section{II 異物事故の統計}

われわれが調查した統計7536例の異物事故に
よる男女別は56対44の比で男子に多く，年令別 では 5 才以下の小児が約半数を占めている。こ のことはジャクソン, クラーフ, ホリンガー等 の報告と一致している。気道食道異物の種類と

\section{第 1 表 気道食道の義歯異物統計}

\begin{tabular}{|c|c|c|c|c|}
\hline 者 & $\begin{array}{l}\text { 発表 } \\
\text { 年度 }\end{array}$ & $\begin{array}{l}\text { 異物 } \\
\text { 数 }\end{array}$ & 義歯| & $\begin{array}{l}\text { 義董 } \\
\%\end{array}$ \\
\hline $\begin{array}{l}\text { 吉田(S) } \\
\text { (1907-1932九大) }\end{array}$ & 1932 & 601 & 78 & 12.9 \\
\hline $\begin{array}{l}\text { 䈎木 (M) } \\
\text { (明42-昭6全日本) }\end{array}$ & 1933 & 508 & 141 & 27.7 \\
\hline Jackson, C & 1936 & 3171 & 142 & 4.5 \\
\hline Clerf, L. H & 1939 & 950 & 48 & 5.0 \\
\hline Matheson, I & 1949 & 602 & 29 & 4.8 \\
\hline 飯沼 (T) & 1951 & 67 & 13 & 19.0 \\
\hline Holinger, P. H & 1954 & 2042 & 75 & 3.6 \\
\hline 小野 ( J ) & 1965 & 7536 & 315 & 4.1 \\
\hline Updlhyaya, D.S & 1966 & 25 & 4 & 16.0 \\
\hline Kakar, P. K & 1970 & 100 & 16 & 16.0 \\
\hline Gupta, O. R & 1970 & 63 & 10 & 15.8 \\
\hline
\end{tabular}

義歯（歯科器具を含む）は全異物例数の5.5\% 


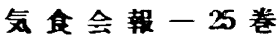

第 2 表 気道食道異物の案計

第4表 画科異物の気道食道能在期間

\begin{tabular}{|c|c|c|c|c|c|c|}
\hline 昭和 & 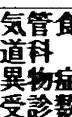 & 道 & $\begin{array}{l}\text { 食道異 } \\
\text { 物 } \\
\text { 入院患 } \\
\text { 者敖 }\end{array}$ & & 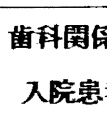 & 智買物 \\
\hline 37 & 132 & 10 & $T$ & 4 & & \\
\hline 28 & 151 & 17 & 13 & 7 & & \\
\hline 39 & 148 & 15 & 11 & 5 & $y->$ & 1 (気) \\
\hline 40 & 150 & 16 & 12 & 6 & 齿 牙 & 1 (氛) \\
\hline 41 & 136 & 11 & 8 & $\overline{5}$ & & \\
\hline 12 & 142 & 13 & 10 & 5 & yーマ & 1 (気) \\
\hline 43 & 138 & 15 & 9 & 5 & & \\
\hline 44 & 141 & 17 & 10 & 6 & 義 齒 & (気) \\
\hline $5 \overline{5}$ & 159 & 17 & 11 & 6 & リーマ & (気) \\
\hline 45 & 147 & 15 & 12 & 8 & & \\
\hline 47 & 149 & 16 & 13 & 7 & & \\
\hline
\end{tabular}

第 3 表 费度病院入院患者の異物症例数

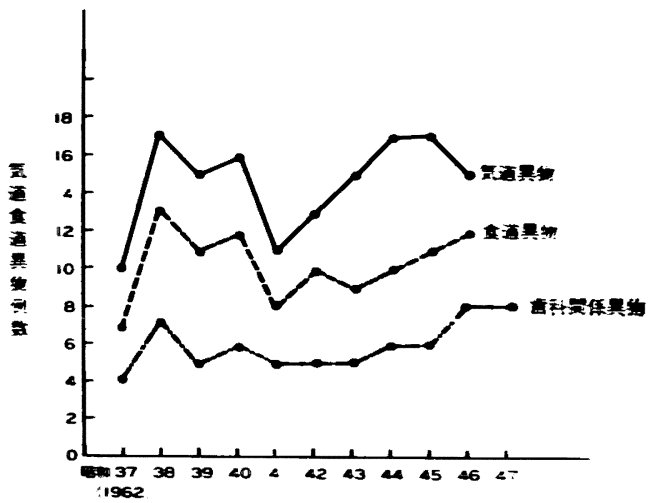

して義画注貨，魚骨に次第 3 位を占めるが 外国の報告を平均方る上 5.5 分だる。（第一 表）特に過去11年間慶庥大学病院における異物 㱏受診例1593例中, 入院患者は気管気管支異物 162例，食道異物116例，計278例である。そのう う画科関邅異物は例である:第 2 表)(第 3 表)

異物の嵌支部位注種類，形状，大きさ等に上 つて異なる扩大多数の義苗は食道入れ部直下部 の Lannier-Hackerman 部で壁の薄蚐部に崖在 する。気道異物としての義画は比教的少なく,

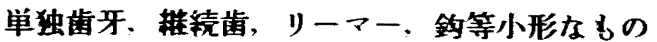
が気管支異物上ふつている。

\section{III 画科異物の崩在期間}

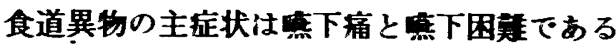
が，貨幣やボタン等と異なり義画異物では疼痛

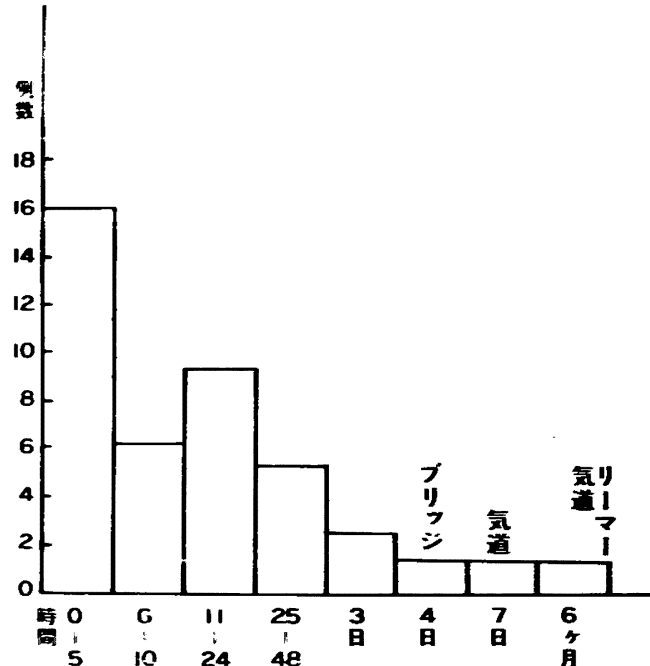

強度のため救急処置を求める例が特に多い。わ れわれの調查群では全例の85\%は事故発生後48 時間以内に摘出処置受け一いる。（第 4 表） 他方気道異物で注耤落,リーマー、フィリン グ等は刺激性が比教的少なく嵌在期間は数力 月，ある例では 8 年の長期に及よ゙ものがあっ た。気道異物で注意すべき应状は事故発生と共

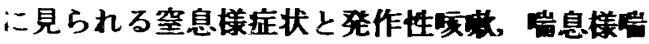
鳴等である。これらの症状は数時間より数日後 に一旦消退し:かゅる「等应状期間」に移行す るこレデある。この「焦症状期間」のため誤診 をまねくこ上となり易い。

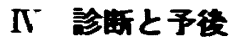

法律で注「疑わしきは罪せす」であるが，異 物の場合この逆で㠜わしきはは，すへて異物 と見なす」な原則としてレ楾検査をはしめ諸唡 查により摧底的に追跡されなけれぼならない。 ここでは直達鏡検查だけに然れるが本検査は診 断と同時に治痖施行が直接結ひつくので不可欠 の診療武器であるこ上は云うまでるなけ。本検

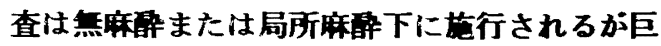
大異物や食道壁に埋没している場合全麻下の掠

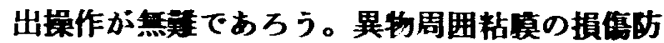
止のため固定器によるイメージスコーブを使用 し好成耫を挙げている。 
義菌異物の予後については笹木はかつてわが 国の文献上，義歯異物 141 例について調查した 結果, 死亡率 $10 \%$ を報告している。抗生剤と技 術の集歩せる今日といえども本症の危険性は軽 視をゆるさない。本症の予後を決定する因子と して (1)異物の種類と形態 (2)異物の嵌在位置 (3)嵌在期間 (4)前医の操作等が挙げられる。わ れわれの本群では死亡例はない。

\section{$\mathrm{V}$ 摘出歯科異物の分析}

直達鏡下に摘出した異物は原則として当方で 保管することとなつているが特別な理由により 患者に返還することもある。在庫義歯61個につ いて次の如く分類検討した。（第 5 表）

上額義歯45個, 下顎義歯 16 計 61 個である。こ れら摘出義菌の大きさの測定は, 各種事情によ り人工歯数によることとした。すなわち人工歯

第 5 表 義歯の食道異物（補釉物）

上颚義歯45個 下䫑義歯16個 計61個 人工歯数による分類

\begin{tabular}{|c|c|c|c|c|c|}
\hline 人工歯数 & $\left|\begin{array}{l|l|l|}1 & 2 & 3\end{array}\right|$ & \begin{tabular}{|l|l|l|}
4 & 5
\end{tabular} & $|6| 7 \mid$ & \begin{tabular}{|l|l|}
8 & 9
\end{tabular} & $|10| 11|12| 13 \mid 14$ \\
\hline 例 & $24|15| 5 \mid$ & \begin{tabular}{l|l|l|}
2 & 2 &
\end{tabular} & \begin{tabular}{|l|l|}
4 & 0 \\
\end{tabular} & \begin{tabular}{|l|l|}
1 & 3
\end{tabular} & \begin{tabular}{|l|l|l|l|l}
3 & 1 & 0 & 0 & 0
\end{tabular} \\
\hline
\end{tabular}

第 6 表 床の範囲

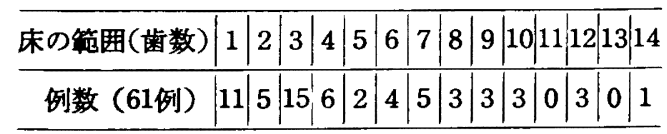
床破損 $\left\{\begin{array}{l}\text { 有 } 30 \\ \text { 無 } 31\end{array}\right.$

第 7 表 摘出義歯と鈎 鈎 $\left\{\begin{array}{l}\text { 有 } 51 \\ \text { 無 } 10\end{array} \begin{cases}1 \text { 例 } & 16 \text { 個 } \\ 2 \text { 個 } & 35 \text { 例 }\end{cases}\right.$ 鈎の形態 $\begin{cases}\text { 良 } & 11 \\ \text { 不良 } & 40\end{cases}$

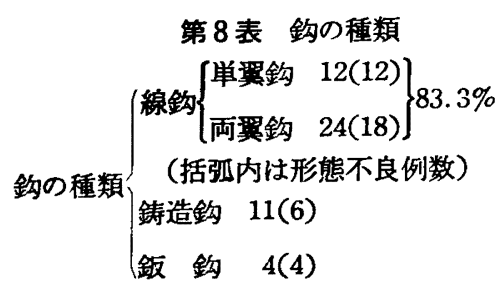

気食会報一 25 巻

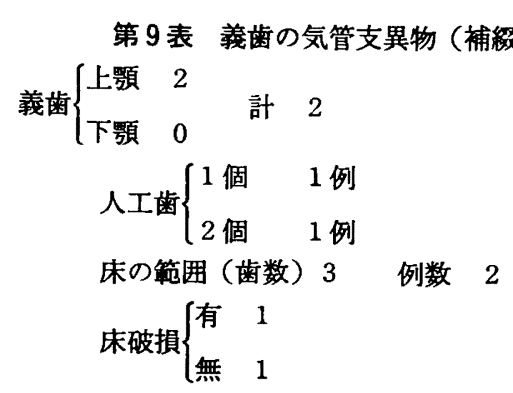

鈎 $\begin{cases}\text { 有（2 個） } 1 \text { 例, 形態不良, 種数線鈎両翼鈎 } \\ \text { 無 } & 1 \text { 例 }\end{cases}$

クラウン 上額前歯 1,2 個連結 - 破損 1 例

" 3/4クラウン前歯 1 , 形態不良 1 例

ブリッジ 上顥(前歯)歯数6-1例, 支台-金属冠2破損

" 前菌-歯数 3 , 支台-継続歯, 3/4クラウン, 形態不良 1 例

継 続 歯 1 例, 形態不良

$$
\begin{aligned}
& \text { 第10表 その他補緅物 } \\
& \text { リンガルバー破折 } 1 \\
& \text { ブリッジ 上額(前菌) } 1 \text {-蒛数 } 7 \text {-例数 } 1 \\
& \text { 下䫟(前歯) } 1 \text {-歯数 } 3-\text { 例数 } 1 \\
& \text { 支台 継続歯 } 4 \text { (合釘短小不良) } \\
& \text { 金属冠 2（支台歯と共に脱落） } \\
& \text { パラタルバー例数 } 1
\end{aligned}
$$

数 4 個以内の義歯は 46 例で全義歯数の $75 \%$ を占 めている。また床の範囲も大小区区なので歯数 を基準として分類した。それによると歯数 4 個 以内の義歯床は37例 $60 \%$ となつている。（第 6 表）

ここで注目したいことは摘出義歯の状態であ る。すなわち義歯床の破損が30個で全例の半数 を占める。（第 7）表また鈎については有鈎義 歯51個のうち形態良が11個, 不良が40個で全体 の約 $80 \%$ となつている。特に線鈎単翼鈎の12個 と鈑鈎の 4 個は全例において形態不良であつ た。（第 8 表）また気管支異物としての義歯, クラウン, ブリッジ等の 6 例, 全例形態不良で あり，その他の補緅物も同様となつている。 （第 9 表）（第10表）

\section{VI 興味ある症例}

ここで最近経験した興味ある 2 症例を挙げ る。

症例 1 
43才男子, 某大学助教授, 初診昭和 48 年 3 月 20 日, 発病, 当日尽食としてシャブシ ヤブを食べていた。ところがその日に新調した ばかりの義歯索誤嚓したという。急に䓵下困難 と激痛を訴え某病院を通し慶底病院に紹介され たのである。レ線検査では義歯は食道入孔部に 嵌在している。（第 1 図）異物は全麻下に摘出 された。

本例で注目すべき点は(1)摘出義歯は新調した ばかり，しかも装着当日に誤瞙されたこと，(2) 義歯使用法に関し画科医より何の注意も受けな

第 1 図

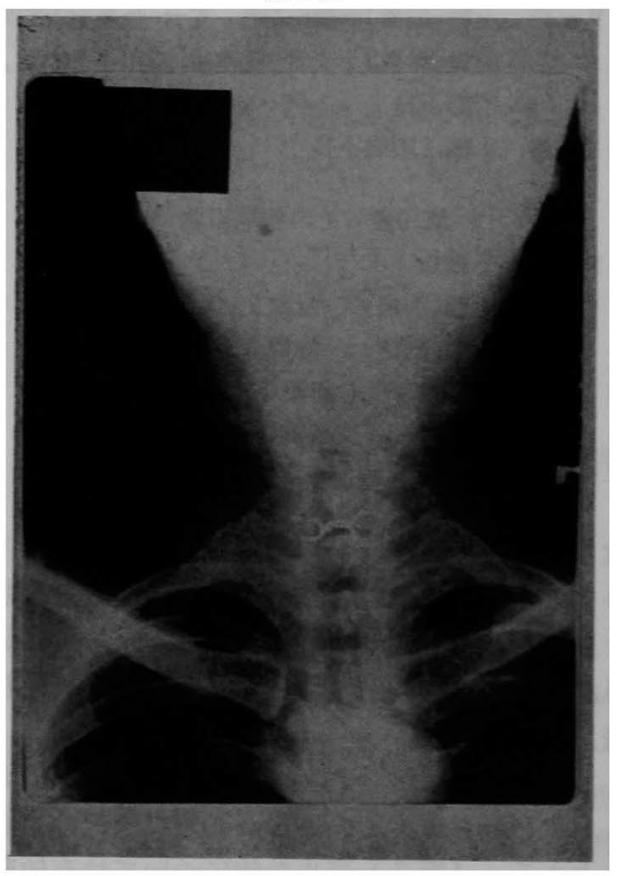

第2图

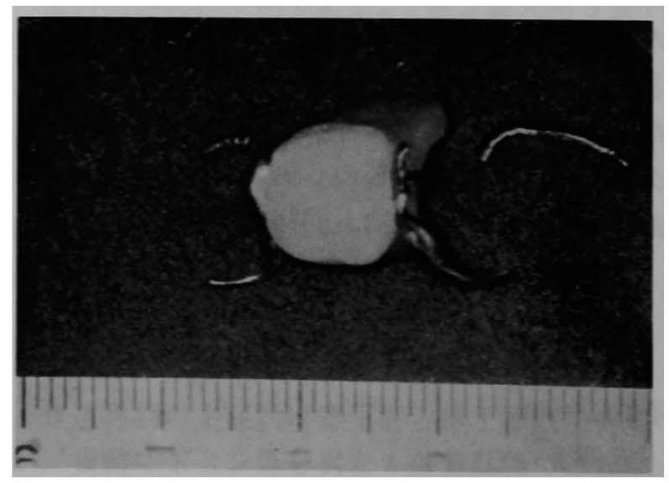

かつたこと、(3)シャブシャブの如き㜞かな食物 で義菌が脱落していること，(4)摘出後この義画 を再び装着せさようとしたところ鈎の一本が折 れたこと等である。（第 2 図）われわれの調查 では鈞が細過ぎ短か過ぎて把握力が薄茨である ことが事故の原因ではないかと思っている。 症例 2

72才男子, 無職, 初診昭和 48 年 6 月 19日, 発病 1 週間前, 歯科治療中充塓物を誤畹 し，その突差にむせたり咳が出たと云う。

この充媜物誤嗼については治療中なので歯科 医も患者自身も気ついていた。しかし医師か ら2，3 日中に自然排出されるからと云われ安 心して而宅したと云う。

ところが，まもなく咳嫩と発熱が訴えられる ようになつた。このことに気づいた患者の子息 が驚き父近医につれてゆきレ線検查を受けた のごある。見ると右肺に充填物の陰影があり直 ちに慶底病院に紹介されたのであった。(第 3 図)

異物は直達鏡下に摘出されたが（第 4 図）そ の直後, 本学画科の診療を受けたところ,すでに 新調の充填物が装着されていたので鳘ろいた。

第 3 图

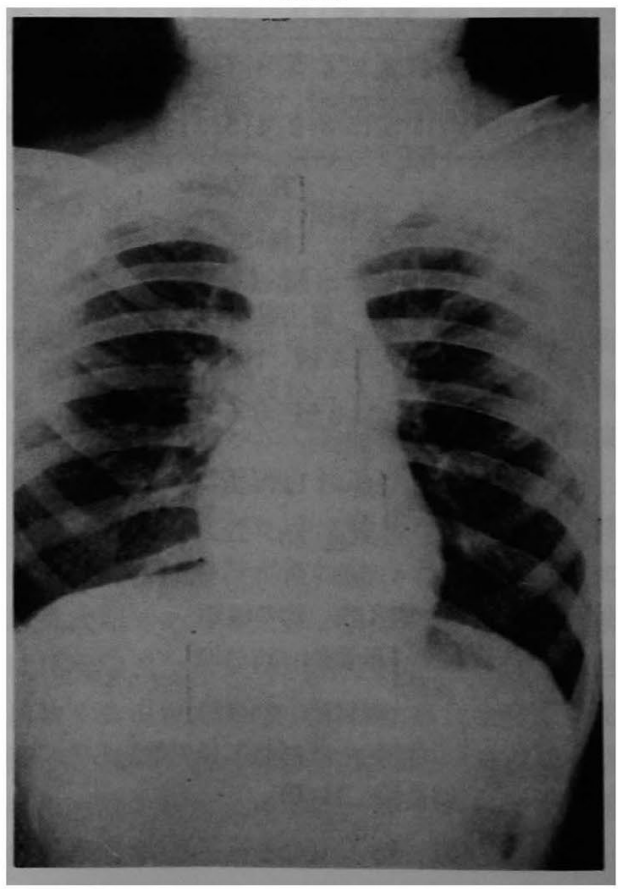




\section{第 4 図}

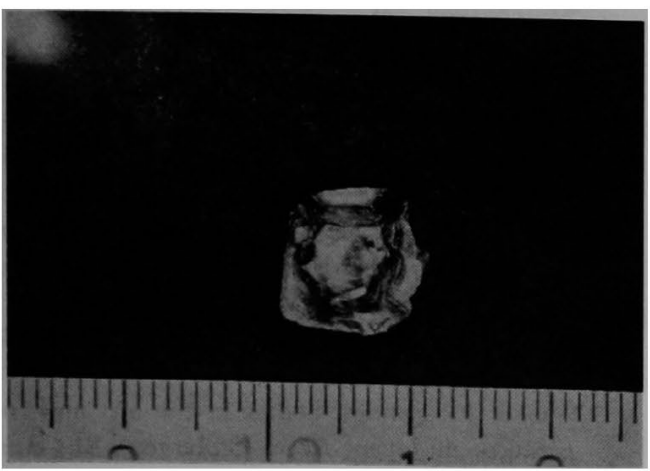

本例で注目されることは，(1)充垻物の誤嬹に ついて医師は無関心であつたこと，(2)誤嚥の突 差にむせたり咳がでたにもかかわらず気道異物 の可能性が考えられなかつたこと（3）レ線検查 が行われていないこと，(4)咳嗽，発熱等気道症 状が現われて初めて異物症が，ほかならぬ患家 の 1 人によつて疑われたこと，(5)事故発生より 1 週間の間, 歯科治療を続けながら医師が異物 に気つかかかつた等が問題点となる。

以上の症例は生命を劦やかす危険性を含むと 共に医療紛争の引金となる可能性が強い。そこ で医療紛争防止について触れたい。

\section{VII 医瘱紛争の防止}

外国では歯科関係の医療紛争は少くないよう だ。わが国でも最近問題視されていることは新 聞の報ずる通りである。そこでこのような事件 の対策として次の基本路線を守りたいものと思 5。(1)歯科診療に当つては常に事故防止に万全 を期す。(2)義歯調整に際しては必ず患者に使用 法を説明する。(3)事故が発生したら直ちに患者 と家族に実情を知らせる。隱蔽することは問題 を複雑化する。(4)事故発生と共に患者を入院せ しめレ線検査を含む精検を行う，(5)専門医に依 頼して速やかな異物摘出を図る，(6)患者側との 人間関係を密にし事態の円満解決を期す, (7)外 来, 入院カルテの精確を期し厳重保管する等で ある。

異物事故防止について義歯使用上の注意は前 述したが，注意事項を各医師または学会が印刷 物として配布し完譬を期するようにしたいもの
である。その注意は次の諸点を含むものとす る。(1)破損または不適合義歯は直ちに修理す る, (2)歯牙, 義歯等口腔内の定期検診の徹底, (3)次の場合脱ずせる義歯は脱ずしておく，(a)寝 床前，(b)全身麻酔，(c)意識言失，(d) 直達鏡検 查, (e)嵒吐嘔気の症状, (f) 発作性咳濑, (g)野外 運動，(d)餅等粘稠物の提取，(i)泥酔等である。 なお食事中の注意として総義歯使用者は口腔内 の感覚が半減されるので少くとも正常人の 2 倍 の時間をかけて咀嚼する習慣をつけることにし たい。

\section{VIII 考案と結語}

以上摘出した義歯及び鈎等の状態を中心に歯 科関係異物について述べた。云うまでもなく局 部義歯の機能的役割とは欠損歯及び軟組織上の 欠損部を補ぎない，咀嚼嬹下発音等の機能障害 を生理的状態に回復するとともに外貌の変化を 防ぎ，歯列及び䫈骨の不正化を予防することに あるのである。

局部義歯の外形は小なるものは 1 歯補経より 大なるもの殆んど総義歯の形を備えるものまで あるが，何れも上記の条件を満たすものでなけ ればならない。

また義歯の維持装置のうちで最も重要なのは 鈎であるが，その機能的条件は次の 如くであ る，すなわち(1)義歯の離脱，(2)動摇等に対する 維持力及び把握力が完全であること，(3)義歯の 沈下を防ぐこと，(4)鈎歯を損傷しないこと，(5) 外観をそこなわないこと，(6)患者に不快感を与 えないこと，(7)口腔内において物理的に安全で あること等が要求される。義歯は常に口腔内に あつて異物を構成し得る最短距離にあることを 銘記したい。

そこで，これらの異物事故の責任は誰が負う べきであろうか。もちろん摘出された異物が証 明するように，磨滅または破折した義歯，また は維持力不全の鈎等の修理を意たつた患者自ら 負うぶきことは云うまでもない。しかし，義菌 製作上の設計, 材料の選択, 作製技術, 装着調 整等の各段階において万全であつたかどうか診 療側としても梁く反省すべきであろう。

医学分野のうちで恐らくは比較し得るものが 
ない歯科という特殊の理論と技術の結晶が義歯 である。この歯科の花形であり健全な食生活の 要具でもあるその義歯が一瞬のうちに生命を妿 やかす凶器と化すことは常識では考えられない ことである。しかも，それがわれわれ臨床家の 目の前に実在するとすれば，あらゆる手段方法 を駆使してその防止に努力せねばならないこと は当然である。

こうした異物防止策を構ずることが結局は義 歯学上の進歩を促がすと共に第13回日本歯科医 学会総会の基調テーマ「未来への歯学と歯科医 療の調和」に寄与することとなるのではなかろ らか。

以上は昭和 48 年 9 月 25 日開催第 18 回日本口腔外科 学会総会（園山昇教授会長）における特別講演の要 旨である。

\section{主要文献}

1) Bunker, Paul G. : The role of dentistry with problems of foreign bodies in the air and food passages. J. Am. Dent. Ass., 64 ; P. 782-784, 1962.

2) Clerf, Louis H. : Foreign bodies in the air and food passages. Surgery, Gynecology and Obstetrics, 70 ; 328-339, Feb. 1940.

3 ) Clerf, Louis H. : Historical aspects of foreign bodies in the air and food passages. Transactions and studies of the Coll. of Physicians of Philadelphia. 4 Sec. 20 ; No. 1,June, 1952.

4 ) Gupta, O.P. : Dentures in the esophagus Int. Surgery., 55 ; 142-148, 1971.

5 ) Holinger, Paul $\mathrm{H}:$ Endoscopic foreign bodies in dental origin. Int. College Surg., $37 ; 284$ March 1962

6 ) Holinger, Paul H. : Dental phases of bronch oscopy. J.A.D.A., 27 ; 84-189, 1940.

7 ）飯沼寿雄，他：食道異物（義歯）の義歯学上の 欠宿とその防止策について。日気食, 2 巻 1 号, p. 14-18.

8 ) Jackson, C. et al. : Diseases of air and food passages of foreign body origin. Philadelphia, The W.B. Saunders Co., 1936.

9) Lavine, Myer H. : J. Am. Dent. Ass., 76 ; 1038-1042, 1668.

10) Ono, J. : Foreign bodies in the air and food passages in Japan. Arch. Otolaryng, 81 ; April, 1865.

11）小野譲：気道食道の異物。日気食, 第 10 巻, 第 3 号, 昭和 34 年 7 月, p. $9-57$

12）笹木実 : 義歯の食道鏡的摘出法。耳鼻咽喉科, 第 4 巻，第 7 号，昭和 6 年 6 月。

13) Szoto, Miklos et al. : Foreign bodies of dental origin in the esophagus. Oral Surg., 34 ; 196-198, 1972.

14) Upadhyaya, D.S. et al. : Particle denture as foreign body in the esophagus and tte bronchus. J. India Dental Ass., May, 1967, 33-34.

15) Wengraf, C.W. : Pharyngo-esophageal foreign bodies in dental wearers. Dental Practit., 19 ; No. 8, April, 1969, 281-282.

16）山川強四郎：気道および食道異物の療法。第15 回日本医学会講演, 昭和 34 年。

I7）山本馨他：わが教室10年間の気道および消化管 異物症の統計的観察。日気食, 第19巻第 4 号, p. 222-233.

18）吉田申次：巨大なる義歯食道異物致死例。耳鼻 咽喉科，第 5 巻第 12 号，昭和 7 年 11 月。 